\section{Utilization of agricultural and forestry resources in Central Guatemalan Highlands: a case study}

\author{
Focacci $M^{(1)}$, Piussi $P^{(2)}$, Ciampi $G^{(3)}$
}

This paper analyses some key findings emerged in the study of the Mayan community of S. José Sinaché, located in the Guatemalan Highlands. The research highlights how colonial and post-colonial legislation influences the actual land tenure and hampers the development of the community. Little land ownership together with high demographic growth lead to insufficient crop production. As a consequence, human pressure on $\mathrm{S}$. José forest and seasonal migration to sugar cane plantations of the Pacific Coast is carried out by householders in order to ensure subsistence to their families. A multisectorial approach must be implemented in order to give socio-economical and environmentally sound answers. New cropping and agroforestry techniques have to be coupled with the reformation of land property distribution and the participation of indigenous communities to decisional processes.

Keywords: Guatemala, Land Management, Deforestation, Farm Labour, Decentralization

\section{Introduction}

The study of the relationships between Guatemalan Mayan communities and the environment has a great importance in the view of understanding the possibilities of development on this country. Many researches have been focused on the advance of agricultural frontier and land management in northern departments, such as Alta Verapaz and Petén, where the large majority of primary forests are concentrated (Shriar 2001 and Shriar 2002, Carr 2004, Gould 2006, Navarrete et al. 2006). However, the use of natural resources in the Central Highlands, where agriculture has been practised since the Mayan age, is of equal relevance. As a matter of fact, in this large portion of the country a relatively high population density and

(1) v. Gramsci, 447, I-50019 Sesto Fiorentino (Florence, Italy); (2) Department of Land Forest Management, University of Florence, Florence (Italy); (3) Department of Geography, University of Florence, Florence (Italy)

\section{@, M Focacci (marcofocacci@yahoo.it)}

Received: Feb 25, 2011 - Accepted: Jun 13, 2011

Citation: Focacci M, Piussi P, Ciampi G, 2011. Utilization of agricultural and forestry resources in Central Guatemalan Highlands: a case study. iforest 4: 242-247 [online 2011-11-03] URL:

http://www.sisef.it/iforest/show.php? id $=579$ colonial and post-colonial policy have modified the structure of rural landscape and emphasised the problem of forest conservation. The aim of the present work is, therefore, to describe the social, economic and environmental factors that drive the exploitation of natural resources within a Mayan community of Central Guatemala. The research appears to be of extreme importance since $80 \%$ of the Guatemalan working force is employed in agriculture and natives represent, numerically, the largest part of this force (CEPAL 2000). The knowledge of the processes, at local scale, that lie behind the use of natural resources allows the organization of broad scale rural development plans. These plans, in turn, may be capable to fulfil the productive requirements of the entire country as well as to preserve the environment and the needs of local communities. Furthermore, a small scale approach matches requirements, goals and methods implemented by the Guatemalan government in the frame of the ongoing decentralisation process started after the peace accords (1996). The passage of land planning competencies to local authorities, which is a common trend in many developing countries (Wily 1999, Kellert et al. 2000 , Bray et al. 2003) constitutes an opportunity to increase efficiency, equity and democracy in natural resource management (Alvarado 2001, Ferroukhy 2003, Santos Zelaya 2003). Nevertheless, without an adequate knowledge of the context in which this strategy is applied, this process can easily become a simple transition of powers with no positive effects on the population. A review of the historical evolution of the rural structure was carried out in order to understand the causes and the processes that have led to the actual structure of the region. The knowledge of the previous socio-economic context permits a better understanding of the current situation and the formulation of environmentally and socially sound development models.

\section{Land tenure in Guatemala from colonial period to present time}

A historical review of the Guatemalan rural structure can provide essential elements for researchers and decision makers since the current situation is deeply linked to the Spanish conquer and the consequent transformations. In 1523 the last Mayan realms fell under the control of the Spanish Crown. In Mayan society the land tenure was structured into three different forms: the agricultural land privately owned either by the population or the aristocracy and communal land (ejidos), used as pastureland. Husbandry production was equally divided between the population and the aristocracy (De Solano 1974). The colonization destroyed this structure and created a feudal system. The Spanish organized large and extensive properties called encomiendas, and the Mayas were forced to work there in slavery conditions. In order to ensure the control on Mayas, traditionally dispersed in scattered settlements, the dominators founded many villages and obliged the population to move in. This strategy was implemented with the support of the old Mayan aristocracy, chosen by the Spanish as a link between them and the population (Bouscayrol 2002). Only the communal lands were left in the native hands thanks to the promulgation of Leyes de Barcelona in 1541-42. The independence gained in 1821 and the further formation of Guatemala (1824) did not produce any relevant change in the productive structure. Great changes were instead caused by the introduction and establishment of coffee plantations in 1850 , immediately followed by sugar cane and banana plantations. In about fifty years the so called Liberal Reformation was carried out and its effects would have influenced the story of the country until the present time. The government, expression of the rich aristocracy, concentrated land property in the hands of the landowners who bought the small properties and expropriated the communal lands. The new cultivations required a great amount of workers and farm labour became the most common way of employment in Mayan communities (Mosk 1958). Natives, firstly, and mestizos without properties, in a second time, were therefore hired as farmers in the large estates. Additionally, the poor lands owned by Mayans were further fragmented and their production 
was no more adequate to support the needs of the population. The chronic under productivity of Mayan properties led, consequently, masses of farmers towards the large properties in search of seasonal work, despite the hard working conditions and low salaries (Solorzano 1970). The effects of Liberal Reformation were hindered, at the beginning of second half on the XX century, by the rising of a middle class whose interests contrasted with those of the old land aristocracy. In 1944 the so called revolutionary period started and led, in 1952, to the agrarian reform. In 1952-53 uncultivated lands were expropriated and redistributed among the population, but a military coup d'etat overthrew the government and cancelled the reforms. By this time the country fell into a long and bloody civil war which lasted about forty years, until the peace agreements of 1996. Nowadays, although the resolution of the agrarian tenure is one of the key statement of peace agreements, an agrarian reformation plan of the country has not yet been implemented.

\section{Study area and data collection}

The present work was realized in the Mayan community of S. José Sinaché in the municipality of Zacualpa, Quiché Department. The Quiché ethnic group, whose the community belongs, occupies the northern west part of Guatemala Highlands, being the most numerous and widespread group even at national level. The municipal territory covers $336 \mathrm{~km}^{2}$. The altitude varies between $1200 \mathrm{~m}$ (Picaché) and $2250 \mathrm{~m}$ (Cerro de los Monos). The southern part is occupied by the Rio Grande valley, in which volcanic ash soils have allowed the formation of a hilly landscape with the presence of badlands in correspondence of sloping areas. The northern part, instead, is mainly mountainous (Sierra de Chuachùs, part of the orographic system of Guatemalan Highlands) with thin soils rich in mica, gneiss and quartz. A typical temperate- hot wet tropical climate characterizes the region with a dry season from December to April and a rainy season from May to November with a mean annual value of $1500 \mathrm{~mm}$. Temperatures are generally mild, annual mean of $18{ }^{\circ} \mathrm{C}$ (maximum 30 ${ }^{\circ} \mathrm{C}$ in April and minimum $0{ }^{\circ} \mathrm{C}$ in December). The $84 \%$ of the population lives in small rural communities. The main occupations are agriculture and breeding, along with a marginal crafting activity. The municipality, one of the poorest of the entire department, is characterized by a fragmented land ownership and a subsistence economy. The precarious socio-economic conditions are indicated by some indexes such as the illiteracy rate $(75 \%)$ and the malnutrition rate $(35 \%)$, fairly higher than national values, $18 \%$ and $23 \%$, respectively (INE 2004).

The community of S. José Sinaché covers
1416 hectares, being one of the largest community of Zacualpa. Considering the terrain characteristics, the territory can be divided into two different zones: a mountainous area, from $1550 \mathrm{~m}$ to $2250 \mathrm{~m}$, with a low population density and important forest cover (about $60 \%$ ), and a flat/hilly area with high human concentration and intensive agriculture.

The data collection has been carried out during a 2 months stay in the community from April to March 2006. The interviews were carried out in Quiché language with the aid of local translators and 57 out of 300 families were interviewed. In order to reduce biased answers, people were not forced to answer to all questions, especially when the respondent did not understand the meaning of the question or did not want to answer. The large majority of families $(83 \%)$ was composed by $5-10$ members, $13 \%$ counted 11-16 members and the remaining $4 \%$ had up to 25 members, with a mean of 8 components per family. The sex ratio was $48 \%$ male and $52 \%$ female. In order to have an exhaustive picture of the socio-economic conditions, questions focus on both agricultural activity and utilization of woody and non woody products. Additionally, information about the demographic growth and the story of the community were collected through bibliographic research and informal interviews. A rough characterization of the forest, in terms of species and typology, was achieved through 10 circular sampling plots (113 $\mathrm{m}^{2}$ each). The sampling point location was randomly selected by using a grid on the available 1:50.000 topographic map. Both "moist low-mountainous subtropical" and "moist subtropical temperate" forest type were investigated (see chapter: "The forestry sub-system").

\section{Results}

The agricultural sub-system and the land tenure

The rural landscape of Guatemalan Highlands preserves the signs of the strong exploitation carried out during the colonial and post colonial period (see chapter Land tenure in Guatemala from colonial period to present time). Whereas other parts of the country such as the Petén and the Sierra de Las Minas forest, located in the North and the East respectively, are interested by an extensive and not permanent agriculture, common of new colonized areas, an intensive and permanent agriculture characterizes the Central Highlands. Within this picture, the community of S. José provides a typical example of the history and the development of mountainous indigenous communities. Furthermore, the analysis of the current socio-economic situation offers a clear idea of the deep and long-lasting modifications on land management produced by the Liberal Reformation. As a matter of fact, the productive structure and land tenure at the time of the foundation of S. José have lasted substantially unchanged. Before 1930 the area appeared scarcely inhabited and mostly covered with pine forests. At that time, landowners established in S. Josè about 45 families of farmers in order to provide housing for those natives who were seasonally employed in the sugar cane plantations located in the Pacific Coast. The pivotal struggle of the Guatemalan productive structure, the contrast between large property and small property land, was therefore created (Cittarella \& Cundari 1988). The farmers, hampered in a chronic condition of dependency from the landowners, were allowed to cultivate small plots of land in marginal and low productive areas of the Highlands in exchange for seasonal work in the fertile plantations of the coastal Lowlands. Passages of property and the civil war did not modify this structure, the situation even deteriorated due to the demographic growth that caused a further fragmentation of the properties themselves. With regard to the number of people living in the community, in 1930 the population was composed of about 40-50 families (300-400 people), grew to 83 in 1979 (650 people) and reached currently 300 families (2380 people). In the period 1930-1979 the demographic growth was quite slow, while in the period 1979-2004 a high demographic increase occurred, showing a mean annual rate of 3.1, fairly above the national value of 2.6 (PNUD 2004). Consequences of such trend have become evident in the last ten year since the population has started to clear the forest and cultivate mountainous steep slopes. Despite the small extension of these areas, this process shows clearly the need of arable land and the subsequent pressure on woodlands.

The land tenure in the community is organised as follows: $7 \%$ of the families owns up to 0.6 hectares, $60 \%$ between 0.6 and 1.2 hectares and $33 \%$ between 1.2 and 1.8 hectares, with a mean of only 1 hectare per family. The small property ownership has determined the development of a subsistence economy in which the main cultivation is maize, used mainly for cooking tortilla. This sort of bun, cooked on plates, is the basis of the every day diet and provides, even at national level, the $72 \%$ of daily energetic needs of Guatemalans (Immink \& Alarcòn 1992). Maize is cultivated with traditional techniques and no irrigation. Of the interviewed families, $11 \%$ has an average maize yield of $900 \mathrm{~kg} \mathrm{ha}^{-2}, 58 \%$ of $1400 \mathrm{~kg} \mathrm{ha}^{-2}, 28 \%$ of $1900 \mathrm{~kg} \mathrm{ha}^{-2}$, and $3 \%$ of $2600 \mathrm{~kg} \mathrm{ha}^{-2}$. Since the mean national yield is $2500 \mathrm{~kg} \mathrm{ha}^{-2}$ (INE 2004), the average value of $1520 \mathrm{~kg} \mathrm{ha}^{-2}$ of S. José appears extremely low. This scarce productivity has to be ascribed to two 
Tab. 1 - Distribution of monthly maize consumption.

\begin{tabular}{|c|c|c|c|c|c|c|c|c|}
\hline $\begin{array}{l}\text { Maize (kg) } \\
\text { /month }\end{array}$ & $\mathbf{0}$ & $1-14$ & $15-27$ & $28-45$ & $46-90$ & 91-135 & 136-180 & $181-225$ \\
\hline $\begin{array}{l}\text { consumption } \\
\text { for humans }\end{array}$ & 0 & 0 & 0 & $9 \%$ & $20 \%$ & $29 \%$ & $28 \%$ & $14 \%$ \\
\hline $\begin{array}{l}\text { consumption } \\
\text { for poultry }\end{array}$ & 0 & $26 \%$ & $34 \%$ & $40 \%$ & 0 & 0 & 0 & 0 \\
\hline $\begin{array}{l}\text { consumption } \\
\text { for pigs }\end{array}$ & $13 \%$ & $20 \%$ & $47 \%$ & $20 \%$ & 0 & 0 & 0 & 0 \\
\hline
\end{tabular}

factors: the low soil fertility of the land devoted to agriculture and the little implementation of simple soil ameliorating techniques, such as crop rotation, due to the small field size. In addition, unfavourable climatic conditions, lack of water, pests and diseases play an important role.

Mexican bean is the second most important cultivation, frequently grown on maize's stems, followed by other vegetable such as tomato, onion, cabbage, pepper and peanuts All vegetables are promptly consumed and only $15 \%$ of the families reaches a productive surplus which is normally sold to middlemen that provide low margins of profit. Besides, home gardens are present in $35 \%$ of livings and their products, avocado (Persea americana), guava (Psidium guajava), cherimoya (Annona cherimola), mango (Mangifera indica), Citrus ssp and banano (Musa paradisiaca), are entirely consumed by householders.

The presence of animals in the community is mainly represented by poultry. All interviewers own chickens and turkeys, $87 \%$ pigs, while only $35 \%$ sheep and a mere $20 \%$ cows. Meat does not normally belong to the family diet, being a sort of emergency food in case of economic difficulty, whereas animal products, such as eggs and milk, constitute an important source of proteins. Sheep and cows, not numerically relevant, are left in the household surroundings or in forest, while poultry and pigs are fed with maize. This practice determines a further decrease in the availability of this already scarce product (Tab. 1). The weighted average of Tab. 1 provides a mean annual consumption of about $2150 \mathrm{~kg}$ for each family (Tab. 2).

The agricultural production cannot absolutely cover the requirements of S. José fa-

Tab. 2 - Monthly and annual maize consumption.

\begin{tabular}{lcc}
\hline $\begin{array}{l}\text { Consumption } \\
\text { type }\end{array}$ & $\begin{array}{c}\text { Tot. monthly } \\
\text { (kg) }\end{array}$ & $\begin{array}{c}\text { Tot. annual } \\
\text { (kg) }\end{array}$ \\
\hline $\begin{array}{l}\text { consumption } \\
\text { for humans }\end{array}$ & 130 & 1560 \\
$\begin{array}{l}\text { consumption } \\
\text { for poultry }\end{array}$ & 30 & 360 \\
$\begin{array}{l}\text { consumption } \\
\text { for pigs }\end{array}$ & 20 & 240 \\
Total & 180 & 2160 \\
\hline
\end{tabular}

milies. With a mean annual production of about $1520 \mathrm{~kg}$ and an average consumption of about $2150 \mathrm{~kg}$, householders need to buy maize. Of the people interviewed, $9 \%$ buy up to $500 \mathrm{~kg}, 56 \%$ from 500 to $1000 \mathrm{~kg}, 15 \%$ from 10 to $1500 \mathrm{~kg}$ and $20 \%$ up to $2000 \mathrm{~kg}$.

Since the land owned by each family is too small to ensure the subsistence, the farmers are obliged to find an alternative source of income outside the community. As already mentioned, this source is to be found in the sugar cane plantations of the Pacific Coast. Although the indigenous working force is not forced any more to work in plantations as at the beginning of the last century, the productive deficit forces anyway farmers to seek seasonal job elsewhere. Of the S. Josè adult males (16-60 years old), $93 \%$ migrate seasonally toward the western coast in order to provide the family with the necessary. Because of hard climatic conditions and high load of work, most of the interviewed persons admit to assume amphetamines during their stay in the plantations. Besides the direct consequences on workers health, the migration affects the entire family: since the community is cyclically populated and depopulated, women and children must supply to men absence with heavy works. Furthermore, the adult male migration causes school abandonment, since children must replace their parents on the every-day work in the farm. This vicious circle does not permit new generations to escape the social exclusion that only the access to education may

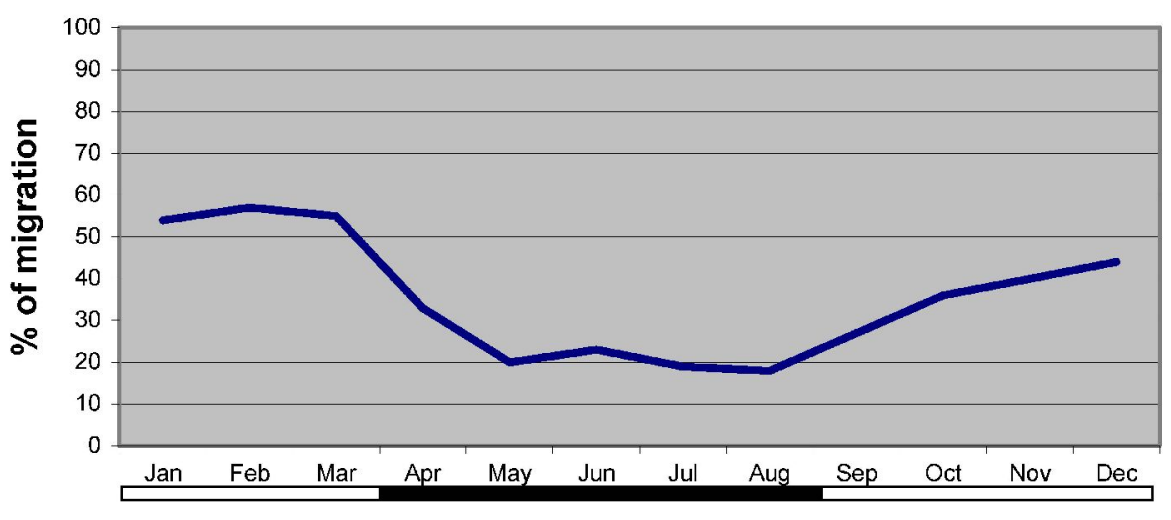

maize cultivation

Fig. 1 - Relationship between maize cultivation phases and seasonal migration to sugar cane plantations. provide. The timing of migration follows the cycle of maize cultivation. From January to March more than $50 \%$ of male population works in plantations. On April the farmers usually go back to their fields to sow maize and accomplish to other cultivation tasks until the harvesting on mid-end of August. Eventually, they return again to the sugar cane plantations until the end of the year (Fig. 1).

Since families depend mainly on the incomes coming from the work in the sugar cane plantations, their economic stability is strictly connected with the price fluctuation in the national and, especially, international market. The farmers cannot influence the price and are constantly subjected to landowners. A typical example of this situation occurred with coffee plantations. As a matter of fact, the economy of entire departments on the Highlands depends on this cultivation and the international crisis of prices from 1999 to 2002 has severely stricken the rural population (Guzmán Merida 2002, especially in those communities where adult males were obliged to work in coffee plantations in order to provide enough incomes for their families. Similarly, a dropping in the sugar cane international price would consequently break the weak economic stability on which the survival of S. José families is based.

\section{The forestry sub system}

According to the Forestry Resource Assessment (FAO, FRA 2000) in the year 2000 forests covered 2.85 millions of hectares, $26.6 \%$ of Guatemalan territory. Among them, the large majority were broadleaves $(82.2 \%)$, then conifers $(9.9 \%)$ and mixed forests (8.9\%). Between 1990 and 2000 the mean annual rate of deforestation was about 54000 hectares and Guatemala, with $15.9 \%$ of total forests lost in ten years, ranked among the first 20 countries in the world (World Bank 2001). Firewood is the most important forest product $(67 \%)$, followed by 
timber (28\%) and secondary products (5\%). Almost the totality of the production is consumed internally and only $10 \%$, mostly timber, is exported (INAB 2006). The major loss of forest cover occurs in the northern departments (Petén and Alta Verapaz) where illegal logging and internal immigration favour the advance of the agricultural frontier. The Highlands, instead, are affected by different problems and dynamics. Here, the human pressure on the environment has been caused by the demographic growth of the last fifty years. This process has led to a progressive land property fragmentation (INE 2004) and, consequently, to the deforestation of large areas for agricultural purposes. Nowadays, conifer forests of Central Highlands are the most disturbed formations in the country and only $9 \%$ of them can still be considered primary forest (FAO 2006. As far as the Quiché Department is concerned, a loss of $11 \%$ of forest cover in the years $1990-2000$ (0.72\% annual ) was observed. In the same period the forest cover in Zacualpa dropped from 14353 to 13684 hectares, with a mean annual rate of $0.43 \%$ (INAB 2006).

The forest of S. José occupies about $60 \%$ of the entire surface of the community and the sample plots have enhanced the presence of two different forest formations. According to the phytoclimatic classification of Holdrige (Holdridge 1947), the highest part is occupied by "moist low-mountainous subtropical forest" where broadleaves such as oaks (Quercus peduncularis Née, Quercus crispifolia Trel.), hornbeams (Carpinus caroliniana Walt. subsp. tropicalis) and alders (Alnus ferruginea Kunth) are predominant. Below the altitude of 2000 meters the pure broadleaved forest is replaced by a mix coniferous and broadleaved forest classified as "moist subtropical temperate forest". Here, pines (Pinus oocarpa Schiede, Pinus montezumae Lamb.) are predominant with respect to oaks (Quercus Conspersa Benth., Quercus Skinneri Benth., Quercus Candican Trel.). The interviews to the community members focused on understanding the type of forest products used in relationship to the population needs, whereas forest surveys aimed at characterizing the different forest formations. In the community, as well as at national level, the most important forest product is firewood, being almost the only source of energy. Pinus oocarpa Schiede is the favourite species being the nearest and most abundant to households. Pinus oocarpa Schiede wood is normally used for cooking meals, as well as used for house heating in the coldest months of the year (January and February). A further consumption of this wood is done by the tuch, a sort of Mayan traditional sauna made of clay bricks, utilized by family components on a weekly basis.

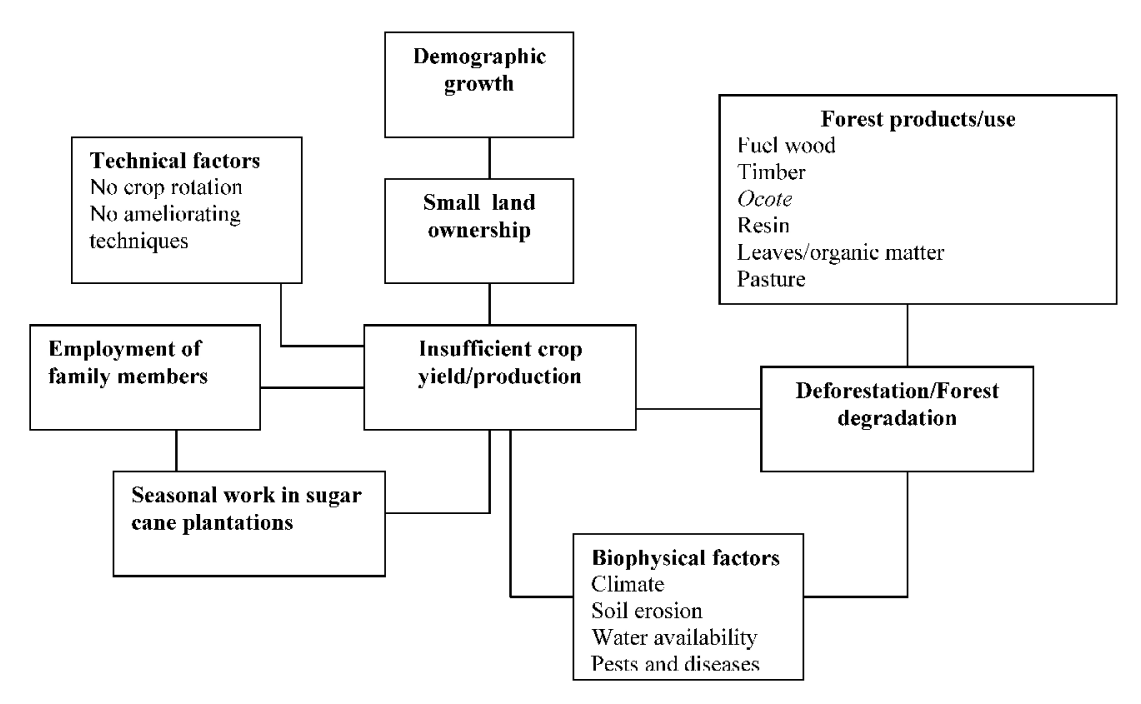

Fig. 2 - A model of the relationships among various social, productive and environmental components in S. José community.

The indigenous measure unit for firewood is the tarea, a stack of $3.36 \mathrm{~m} . \times 84 \mathrm{~cm} . \times 43$ $\mathrm{cm}$. constituted by $10 \mathrm{~cm}$ diameter cordwood and equal to a wood volume of about 0.74 $\mathrm{m}^{3}$. During the survey a significant difference in consumption was noticed between those households in which a stove (distributed by the government at the end of the 80 s) was present and those in which a traditional open fire was still in use. A total of $72 \%$ of families owns and utilizes a stove for cooking and only $28 \%$ either cooks on open fire or does not use the stove. If we assume a mean annual consumption of $14.4 \mathrm{~m}^{3}$ (one tarea per month), the comparison between stove and traditional open fire users provides interesting results. As a matter of fact, the monthly average firewood consumption with open fire is $1.24 \mathrm{~m}^{3}$ per family, against a significant $0.79 \mathrm{~m}^{3}$ where stoves are utilized. This datum highlights that the usage of stove allows to save up to $36 \%$ of firewood. The efficiency of stoves is perceived even by the population: only $19 \%$ of interviewed people do not find any difference, $23 \%$ recognize the difference but is not able to give a quantification, while $23 \%$ affirm to save up to $25 \%$ and almost half of interviewees (53\%), declare to spare even $50 \%$. As a consequence, the use of simple and easily accessible technologies such as stoves seems to play an important role in the exploitation of a limited natural resource.

Even if firewood is the most utilized forest product, also timber is important as building material. The typical house is composed by five rooms, the walls are made of clay bricks and timber is used for roof structures, doors and windows. The timber consumption was calculated by taking into account both answers obtained during the interviews and field survey data. This method proved to be necessary since inhabitants were not able to quantify in terms of volume the precise amount of timber felled. Of the people interviewed, $45 \%$ declared to use "two trees" to build a house, $37.5 \%$ "three trees", $13 \%$ "four trees" and $4.5 \%$ "five trees". Considering that, from field survey, the standard tree used for timber shows a diameter (d.b.h.) of $45-50 \mathrm{~cm}$ and a height of $25-28 \mathrm{~m}$, a unitary value of $1.6 \mathrm{~m}^{3}$ can be derived, with an average consumption per family of $4.43 \mathrm{~m}^{3}$. Because of the scarce durability of pine wood and the absence of conservation treatments, householders are forced to reconstruct periodically their house. A total of $49 \%$ of individuals need again new timber every 5-8 years, $19 \%$ every $9-12$ years, $21 \%$ every $13-$ 16 years, $6 \%$ every $17-20$ years and $5 \%$ every $21-25$ years, with an average interval of 10 years. The data collected show that firewood and timber requirement reaches the value of about $15 \mathrm{~m}^{3}$ per year in each family, with a predominance $(96 \%)$ of firewood. Comparing this percentage with the national datum (67\%), a high rate of consumption and dependence on firewood is highlighted in the community. From a qualitative point of view, big trees are preferred for timber utilization while medium or small size trees are used for firewood.

Also secondary forest products are extracted from S. José forests. The most important product is certainly the ocote, wood chips impregnated with pine resin and used as fire tinder. The ocoteros obtain the ocote by progressively excavating the trunk. In this way the resin impregnates the wood, until the death of the tree. This product is normally sold in local markets, representing, however, a negligible source of income. The practice of resination through stem carving is rarely implemented since the resin is burned as in- 
cense only during traditional Mayan ceremonies. In addition, two other activities affected the forest regeneration and preservation: pasture of cows, sheep and goats and leaf collection, used either as a manure or, in addiction to clay, to produce house bricks.

Because of the social and political situation caused by the civil war, an accurate inventory to determine the forest growth and, consequently, the sustainability of the current rate of firewood and timber consumption was not undertaken. The passage from fores to cultivated field of many steep sloping areas together with the building of new houses shows however the strong and increasing pressure on woodland. The diagram in Fig. 2 resumes the relationships among socio-economic and environmental factor within the S. Josè community. The systemic insufficient crop yield derives from the smal size of crops due to the demographic growth which has progressively fragmented land property. Furthermore, this fragmentation does not allow the implementation of ameliorating soil techniques such as crop rotation. Also biophysical factors, among them climatic adversities, water scarcity, soi erosion and incidence of pests and disease, contributes to decrease the agricultural productivity. This situation increases the pressure on the forest since people require land to cultivate. In turn, the loss of forest cover along with other practices that degrade the $\mathrm{S}$ Josè forest, such as resin extraction, organic matter and leaves collection, ocote production and pasture of sheep and cows, cause further soil erosion and water cycle unbalance. Another effect of the insufficient crop production is the seasonal migration to sugar cane plantations. Again, a vicious circle is fostered: on one hand adult males must work under extremely hard conditions with direct effects on their health, on another hand children must replace their parents when are far from the family and are therefore forced to abandon the school.

\section{Conclusions}

The study of the historical, economic, social and environmental context of the S. José community allows to formulate some considerations on the present and future perspectives in the management of natural resources in the Guatemalan Highlands. The actual land system can be considered as the final phase of a process originated during the Spanish conquer. Little impacting land exploitation and low pressure on forests, typical of Mayans extensive cultivations, changed dramatically with Spanish colonization. In this period the construction of new settlements aimed at concentrating and controlling the indigenous population (Veblen 1976, CAMCORE 1985) increased deforestation and impact on the environment During the colonial period and especially with the Liberal Reformation of 1871, land tenure order came to its actual structure. The land ownership dichotomy - large estates and small farms - became the backbone of the productive system: small and low productive plots in the Highlands were left to the indigenous labour who was consequently forced to work seasonally in the large and rich plantations of the coastal Lowlands to ensure their survival. The already little land availability has been increasingly reduced in the last decades because of the demographic growth that has led to a further land fragmentation and a constant productive deficit. As a consequence, adult males are obliged to look for an alternative source of income that is uniquely ensured in the sugar cane plantations though hard work condition and low salaries. The need of arable land and the collection of forest products such as firewood and timber determine an excessive pressure on the forests. The ongoing deforestation, thus, activates a vicious circle in which erosion, water cycle unbalance, microclimatic changes negatively affect the agricultural yields and the forest renovation.

From what mentioned above, it appears extremely important to undertake actions for the conservation of the mountains forest of Guatemala. Nevertheless, the complexity of factors interacting in the communities requires multisectorial answers: beside technical solutions, effective management plans must be carried out in order to involve the entire population in forest conservation. The redistribution of lands constitutes undoubtedly the pivotal node in the planning of a new land system and management of the Highlands. Beside the agrarian reformation, technical solutions must be taken into account in order to increase crop yields and reach both food security and sustainable use of natural resources. The most important cultivation which requires an improvement is surely maize, being the basis of the indigenous alimentation. Genetic selection and improvement of local varieties may have a comparable importance. After the peace accords many projects have been implemented and positive results could favourably influence maize yields. Regarding the exploitation of forest products, the implementation of agroforestry systems could reduce the pressure on the forest by providing firewood and timber as well as other products such as forage and green manure. The criteria for the selection of the most suitable species should be: rate of growth, wood and foliage quality and nitrogen-fixing ability. In addition, these species should be already available in the community. This is an important aspect to be considered since the implementation of new techniques could be more easily developed by using species which are already grown by the farmers. For these reasons, Alnus acuminata Kunth., Casuarina equisetifolia
Forst and Grevillea robusta Cunn. may be selected for this purpose.

Along with any technical proposal, which effectiveness is linked to many factors (costbenefit feasibility, applicability with respect to biotic and abiotic components, etc.) social and political aspects such as the relatively new migration trend towards the U.S., need to be considered. The remittances of emigrated relatives are remarkably changing the economy of indigenous communities, and the social and economic effects must be carefully studied. As already observed in Mexico (Jones 1995) and in other parts of Guatemala (Taylor et al. 2006), the remittances are mainly used for the elevation of the single family status more than of the community as a whole.

The development of S. José and the other communities of the Highland, however, cannot be achieved without the involvement of the population in the decisional processes. The ongoing decentralization is a unique chance to ensure a territorial planning where, through negotiation and real democratic participation, the conservation of natural resources may be coupled with the satisfaction of the needs of people. In order to include the less powerful parts of the population in this process is therefore necessary that local institutions legitimate and encourage representation of the communities (Nygren 2005). At the same time, the decentralization must be accompanied with a collective action inside the communities through the formation of associations and cooperatives, in order to create a network of forces that can significantly contribute to the amelioration of life conditions.

\section{References}

Alvarado C (2001). Directrices praticas para la evaluaciòn, mediaciòn, implementaciòn $\mathrm{y}$ seguimiento del los criterios y indicadores a nivel nacional para el manejo sostenible de los bosques de Centro América. FAO, Rome (Italy), pp. 4-23.

Bouscayrol MT (2002). Historia social del norte de Huehuetenango. CEDFOG, Huehuetenango, Guatemala, pp. 75-102.

Bray DB, Merino-Perez L, Negreros-Castillo P, Segura-Warnholtz G, Torres-Rojo JM, Vester HF (2003). Mexico's community-managed forests as a global model for sustainable landscapes. Conservation Biology 17 (3): 672-677. - doi: 10.1046/j.1523-1739.2003.01639.x

CAMCORE (1985). Abies guatemalensis - a two years status report. Bulletin on Tropical Forestry 3, CAMCORE, North Carolina State University, Raleigh, NC, USA, pp. 21-24.

Carr DL (2004). Ladino and Q'eqchí Maya land use and land clearing in the Sierra de Lacandón National Park, Petén, Guatemala. Agriculture and Human Values 21 (2/3): 171-179. - doi: 10.1023/B:AHUM.0000029397.69419.11

CEPAL (2000). Información básica del sector 
agropecuario.Sub-región Norte de América Latina y El Caribe 1980-1999. Comisión Económica para América Latina y el Caribe de Naciones Unidas, México DF, pp. 45-48.

Cittarella F, Cundari G (1988). Guatemala, dipendenza e squilibri territoriali. Università Federico II, Loffredo Ed., Naples, Italy, pp. 79-84.

De Solano F (1974). Tierra y sociedad en el reino de Guatemala. Editorial Universitaria, Universidad de S. Carlos, Ciudad de Guatemala, pp. $60-$ 131.

FAO (2006). Inventario Forestal National 2004. Guatemala. (CD-ROM).

Ferroukhy L (2003). La gestiòn forestal municipal en América Latina.CIFOR, Ottawa, Canada. (CD-ROM).

Gould K (2006). Land regularization on agricultural frontiers: The case of northwestern Petén, Guatemala. Land Use Policy 23 (4): 395-407. doi: 10.1016/j.landusepol.2005.03.002

Guzmán Merida PL (2002). Estrategias de vidas de las personas relacionadas con el café debido a la baja de precios en Huehuetenango. Magna Terra Ed., Guatemala, pp. 35-68.

Holdridge LR (1947). Determination of world plant formations from simple climatic data. Science 105 (2727): 367-368. - doi: 10.1126/science.105.2727.367

Immink MDC, Alarcòn JA (1992). Household food security and crop diversification among smallholders farmers in Guatemala: can maize and beans save the day? Food, Nutrition and Agriculture 2 (4): 32-41.
INAB (2006). Boletín Estadistico 2005. Ciudad de Guatemala, Guatemala. (CD-ROM).

INE (2004). IV Censo Nacional Agropecuario. INE, Guatemala. (CD-ROM).

Jones R (1995). Ambivalent journey: U.S. migration and economic mobility in north-central Mexico. University of Arizona Press, Tucson, AZ (USA), pp. 23-27.

Kellert S, Mehta J, Ebbin S, Lichtenfeld L (2000). Community Natural Resource Management: Promise, Rhetoric, and Reality. Society and Natural Resources 13 (8): 705-715. - doi: 10.1080/ 089419200750035575

Mosk SA (1958). Economía cafetalera de Guatemala durante el período 1850-1958, Economía de Guatemala, Seminario de Integración Social Guatemalteca, pp. 172.

Navarrete MN, Slocombe S, Mitchell B (2006). Science for place-based management: lessons from the Maya Forest (Chiapas and Petèn). Ecology and Society 11 (1): 8. [online] URL: http://www.ibcperu.org/doc/isis/8583.pdf

Nygren A (2005). Community-based forest management within the context of institutional decentralization in Honduras. World Development 33 (4): 639-655. - doi: 10.1016/j.worlddev.2004. 11.002

PNUD (2004). Informe sobre desarrollo humano 2004. La libertad cultural en el mundo diverso de hoy. Mundi-Prensa Libros S.A., Mexico DF. (CD-ROM)

Santos Zelaya JA (2003). Applicaciòn de criterios e indicadores en las aréas de trabajo del proyecto
MAFOR para evaluar el estado del manejo forestal. PROCAFOR, Tegucicalpa, Honduras. (CDROM).

Shriar AJ (2001). The dynamics of agricultural intensification and rResource conservation in the buffer zone of the Maya biosphere reserve, Petén, Guatemala. Human Ecology 29 (1): 27 48. - doi: 10.1023/A:1007191621234

Shriar A (2002). Food security and land use deforestation in northern Guatemala. Food Policy 27 (4): 395-414. - doi: 10.1016/S0306-9192(02) 00046-5

Solorzano V (1970). La evolución económica de Guatemala.Economía de Guatemala, Seminario de Integración Social Guatemalteca, pp. 62.

Taylor M, Morantaylor M, Rodmanruiz D (2006). Land, ethnic, and gender change: Transnational migration and its effects on Guatemalan lives and landscapes. Geoforum 37 (1): 41-61. - doi: 10.1016/j.geoforum.2004.12.002

Veblen T (1976). The urgent need for forest conservation in highland Guatemala. Biological Conservation 9 (2): 141-154. - doi: 10.1016/ 0006-3207(76)90046-X

Wily L (1999). Moving forward in African community forestry: trading power, not use rights. Society and Natural Resources 12 (1): 49-61. doi: 10.1080/089419299279885

World Bank (2001). World Development Indicators. Communications Development Incorporated, Washington, DC, USA. (CD-ROM). 